\title{
Study on the Efficiency Assessment of Public Finances Purchase Private College Education Service
}

\author{
Chaoyang Yuan ${ }^{1, a}$ \\ ${ }^{1}$ Xi'an International University, Xi'an, Shaanxi, 710077 \\ ${ }^{a}$ email
}

Keywords: Educational Services, Public Finance, Private University

\begin{abstract}
Private colleges and universities is an important component of our education system, government financial help is an important guarantee for development of private colleges. The current government support private higher learning institutions from the direct financial investment to purchase educational services change, government finance purchasing private higher education services has more conducive to improve teaching quality of private universities. Public finance purchases educational services to colleges and universities to introduce competition mechanism to the formation of healthy competitive environment. Public finance purchase educational services can help to form an atmosphere of cooperation, to achieve the government, universities and private investors tripartite win. But later on the Education of Public Finance Service also needs to do a good job supporting the work, improve the relevant body, clear the contents of the purchase, operation and the establishment of monitoring mechanisms, and improve government finances the purchase of private higher education services, improve the efficiency of the use of public finances, but also better safeguard and promote the development of private colleges and universities.
\end{abstract}

\section{Introduction}

Private College as a major component of higher education in expanding educational opportunities, personnel training has played an important role. After the implementation of our expansion policy, private colleges and universities are to obtain rapid development opportunities, the number of private colleges and continuously upgrade the quality. However, the government's attitude is the key to support the development of private colleges and universities [1]. For private colleges and public universities, government financial support is to ensure that the fundamental forces of school education development, but different government expenditure Private Universities and Public Universities obtained, lack of government financial support for private colleges and universities for education efforts. To solve this problem, the Government has introduced later education service system to ensure that the strength of Running Private Colleges, better realize the value of Private Colleges and Universities.

\section{Public Finance Purchase of Private Services to Higher Education}

Public finance the purchase of educational services is based on the government to provide education service evaluation Private Universities signed a contract with the private colleges and universities, public finance payment of all or part of the cost, and provide more quality and efficient services. For its part, the purchase of public finances on the Education service is a new way of fiscal responsibility, important for colleges and universities, government, and other related subjects.

The Introduction of Competition Mechanism and Promotion University School Quality. Public Universities organized by the government and operate, easy to form a monopoly situation. After public colleges and universities to create a monopoly, lack of competition, lack of education to improve the quality and efficiency of the power source between Colleges and Universities. The government may purchase educational services of the University in introducing competitive mechanism to promote competition among private colleges and universities as well as between private and public universities. On the one hand, the government adopted bidding mode select qualified private universities, only better access to government financial support to colleges and 
universities qualified to ease the burden on the school to improve the quality of higher education schools do to enhance the school's reputation [2]. On the other hand, after obtaining government support and private colleges and universities do to improve the quality of students quality of private universities will also enhance students squeeze public universities. For universities, the quality of students is an important part of school quality decisions. Overall, public finance for the purchase of educational services in the form of private colleges and universities can make a good competition among colleges and universities formed to promote public universities and private colleges and universities to strengthen management, enhance the level of education.

Participation of Each Mode Change. Public finance the purchase of private higher education institutions to introduce third-party services will run Colleges and Universities, schools and government so that the original two-party involvement mode to the government, schools and the community to participate in tripartite model [3]. After the public finances the purchase of private higher education services, more social power and resources into the cause of higher education, school principal cause of higher education has gradually become more diversified direction. Our country is a socialist country, the government has more advantages in the provision of private higher education services, the Government can mobilize a large number of financial and material resources and services colleges and universities, to provide protection for citizens to receive higher education. Under the traditional management model of higher education, the Government has undertaken major financial and human resources and effort required for development of universities, government unilaterally governance model diversification and private colleges and universities can not meet individual needs. Government departments and the lack of sense of service, can easily lead to the abuse of power problems. After the public finances the purchase of educational services, the government can make use of social resources to make up for government "powerless" and "market failure", third parties are more willing to bear the lack of "interest" of educational services, and services to meet the diverse needs of Private Higher Education.

The Transformation of Government Management. Our Government Management Model for transition period, the government undergoes a transition from a disease management model to a service-oriented. Under the managed mode, the government's management of private colleges and universities in a single provision of public goods, a government service mode can be used to purchase financial education services to private educational institutions, government and private colleges and universities to cooperate and provide public goods and services. Government purchases of private higher education reflects the education service controls gradually relaxed, but also meet the requirements of social division of labor. Meanwhile, the public finances the purchase of private higher education service is a concrete manifestation of the transformation of government functions. After the government purchase of private higher education services, government managers to shift from direct service providers. Just focus on fulfilling government policy-makers, buyers and education services supervisor duties, education management authority truly return to society. After the government purchase of private higher education services, education and the supply sides to achieve independence, in favor of both sides to give full play the advantages of supply, more economical and efficient completion of educational services. Government is no longer a monopoly of power, other public centers of power are no longer in the position of manager of the government, but mutual cooperation, equality and mutual benefit.

To Achieve Win-Win Situation. Public finance the purchase of private higher education services to achieve the government, universities and private investors win, so that participants can benefit from the individual. First, the government purchase of educational services can promote the development of private universities, the use of powerful social forces to pressure the government to share the cause of education, the government can also concentrate more for education, financial capital also significantly improve operational efficiency. Second, the government purchase of private higher education services to private colleges and universities to bring more money, school quality of private universities have a more solid financial support, non - governmental university's enthusiasm also significantly increased. Finally, the Government later on the Education Service can absorb more private capital into education, broaden the investment channels of social capital. 
Private investors may be able to derive financial returns, strengthen the investor's reputation in society.

\section{Measures to Improve Public Finances Later on the Education Service System}

At present, some regions of the introduction of public finance the purchase of private higher education services system for sharing the financial burden of private education. But the government later educational system lacks experience related institution building is lagging behind, while foreign governments have more experience in the purchase of educational services. Our government needs according to China's basic national conditions, drawing on foreign experience, improve the public finance system purchase educational services.

Specifically Related to the Subject. Government purchases of private higher education services include three main: buyers, service providers and recipients. Education Services purchaser refers to local governments and related departments, buy body need to do financial planning, allocation of part of the financial resources for the purchase of private higher education services, education and services for the purchase of financial funds into the government budget [4]. The central government should be the policy guidance and financial support for local government purchase of private higher education services to provide policy and financial support. Educational services provider means all types of colleges and universities, private colleges and universities need to accept the government's supervision and guidance, and to compete with other private colleges and universities, and the government do a good job of education. Service recipients should mainly refers to all types of private schools, in view of the level of development of our education, government purchase private vocational education Higher Education service oriented. Vocational education is the main mechanism to improve the quality of workers, help to improve the employment rate, and promote the transformation of labor, and provide more technical people. Government purchases of private vocational higher education services can generate greater economic and social benefits.

The Establishment of Private Higher Education Services Later Operating Mechanism. Former government purchase of private higher education services, education should be the first based on the required services, social needs, financial arrangements, making purchasing plan. Second, the collection of private colleges and universities information, private colleges and universities are in clear conditions. Finally, the government released to the community to purchase educational services related to content, including the need for private colleges and universities, to the public tender. Bidding process requires strict accordance with processes, including the assessment of the qualifications and ability of private colleges and universities in terms of teaching staff of private colleges and universities, financial situation, school conditions, to determine whether private colleges and universities to meet the requirements [5]. In addition, according to the principles of fairness require bidding, notary public and conducted to ensure participation in the bidding subject enjoy equal rights.

To Strengthen the Purchase of Private Education Services Supervision System. Government purchases of private higher education service process, the need to take the necessary supervisory measures to provide health education services supervision. First, the government should provide health education services charged with the supervision of principals. Although the purchase of private higher education services shift responsibility of government measures, but the government still assumed responsibility. In essence, the government purchase of private higher education service market is the transformation of education, but the government is still involved in education, and education is still the main building. Government purchase of educational services mode, governmental responsibilities change, the role of government is mainly responsible for the purchase and oversight responsibilities. Therefore, the government needs to establish a system of supervision visits, regular visits with educational services. Second, we can introduce a third party supervision system, or directly set the third-party oversight body. Our public services tend internal evaluation, the higher authorities to subordinate work for examination, regardless of external views on its work. But the public is the main recipients of social services, public social services, the evaluation should be the subject of evaluation. Thus the government can establish a third-party rating agencies, 
establish a fair assessment mechanism, the public evaluation as the main indicator of the quality of public services, building alignment type external evaluation system.

Establish the Purchase of Educational Services Supporting System. Improve public finances later on the Education service efficiency not only need to be clearly related to the subject, to establish operational and supervisory system, also need to establish a sound financial and information system. Government purchases of private education and services need capital as a guarantee, is also dependent on government funding. Thus the government for the purchase of private funding of higher education and services need to set up separate accounts, closed patrolling, and strengthen supervision and management, improve capital utilization. In addition, information is one of the core elements of a modern competitive, ensure that the information collected is complete elimination of basic government purchase of educational services of asymmetric information [6]. Therefore, the need to establish an information intermediary and professional service providers responsible are for collecting education agency qualification, level. Smooth government issued later on the Education and delivery service channels, use of new media publish bidding information.

\section{Conclusion}

Public finance purchase private higher education services is important to promote the development of education innovation, performance is an important transformation of government functions, in favor of a diversified pattern of school. Although public finance purchase private higher education services the country, but the service quality and cost have problem, especially for the education sector, there are many loopholes in the implementation process easy trade-off in government purchase educational services process. Thus, different actors need to establish risk awareness, improve the system from the start, in order to play the role of public and private finance purchase advantages of higher education and services to meet the requirements of the development of education.

\section{Acknowledgements}

Department of Education research project of Shaanxi Province "Public Finance and services purchased on the Education Effectiveness Evaluation" (14JZ041) initial results.

\section{References}

[1] Zhou Cuiping. Government purchase educational services connotation, types and Prospect [J]. Global Education, 2010, 08: 72-77.

[2] Zhou Cuiping. Government Purchase Situation and education services - Analysis based on the Shanghai Education Commission Management [J]. Educational Development, 2011,03: 39-44.

[3] Wang Lingyan, Liu Ying. Western governments later (education) services background, operation mechanism and its problems [J]. Pre-school Education Study, 2011, 05. 9-14.

[4] Liu Yushan, Wang Yang, Ji Peng. Government to buy the operating mechanism of vocational education services, and the plight of practice development path [J]. Educational Development, 2014, 19: 13-19.

[5] Yan Hai, Meng Na. Development of private education financial responsibility- education services for the government purchase centers [J]. Modern Education Management, 2013, 09: 106-110.

[6] Tang Chi. Assess the role of education in the government purchase of educational services Exploration and Practice of Shanghai Pudong New Area [J]. Education Development Research, 2007, 07: 47-49. 